\title{
Studies on the Phenology of African Breadfruit (Treculia africana Decne) in South Eastern Nigeria
}

\author{
Amujiri A. N. ${ }^{1, *}$, Nwosu M. O. ${ }^{1}$, Nzekwe U. ${ }^{1}$, Osayi E. E. ${ }^{1}$, Sani M. B. ${ }^{2}$ \\ ${ }^{1}$ Department of Plant Science and Biotechnology, University of Nigeria, Nigeria \\ ${ }^{2}$ Department of Biology/ Education, Federal College of Education (Technical), Potiskum, Yobe State, Nigeria
}

Copyright $\bigcirc 2018$ by authors, all rights reserved. Authors agree that this article remains permanently open access under the terms of the Creative Commons Attribution License 4.0 International License

\begin{abstract}
Studies on the phenology of African breadfruit (Treculia africana Decne) Moraceae was carried out monthly for three years $(2012$ - 2014) in five Southeastern States of Nigeria in two seasons, dry and wet. The study covered five towns across the States namely: Isulabor (Abia), Agulu (Anambra), Ezzamgbo (Ebonyi), Nenwe (Enugu) and Mbato (Imo State). The species was investigated to provide information on the species periods and pattern of leaf exchange, leaf dispersal, flowering, fruit formation, maturity and dropping. The species is semi-deciduous and fruits throughout the year with two fruiting periods (heavy and lean) which alternated each other. The reproductive and vegetative phenophases overlapped each other. The observations were consistent in all the location. Early October showed various degrees of vegetative growth; bud flush, leaf formation, maturity and leaf abscission, which spilled into November thus starting the dry season phenophases. In dry season, light flowering, fruit formation and maturity stretched from November to late March, while fruit dropping lasted from February to March. April as in October also showed various degrees of vegetative growth which spilling into May in the wet season. In the wet season, heavy period of flowering was from May to June, fruit formation, maturity, ripening and dropping began from July to September. These periods were shorter in the wet season than that of the dry season. $T$. africana had highest fruit dropping (heavy periods) in the wet season, alternated with lean periods in dry season. Therefore, the species is an indigenous Nigerian food crop that can mitigate seasonal food scarcity throughout the year.
\end{abstract}

Keywords Treculia africana, Reproductive Phenophase, Vegetative Phenophase

\section{Introduction}

African breadfruit (Treculia africana) Decne, belong to the family Moraceae, order Rosales and genus Treculia. The tree is a forest and wetland species capable of growing up to $30-45 \mathrm{~cm}$ in height and $3 \mathrm{~m}$ at full maturity $[1,2]$. The tree bears fruits on the main trunk and big lateral branches, and can be planted some distance away from residential areas to avert the danger posed by its heavy, large fruit which is not traditionally harvested but allowed to ripen and drop from the tree $[1,3]$. The plant has dichotomous branches with spreading umbrella-shaped canopy, fluted trunk, thin, smooth or spineless bark which is dirty green when juvenile and grayish or white patches when mature and buttress rooting pattern [4]. The leaves are glabrous, forest green in colour and leathery to touch; the fruit and flower are globose, and fruits weigh about $10-25 \mathrm{~kg}$ with a diameter of $10.5-20.5 \mathrm{~cm}$ [5]. However, the fruit weight is dependent on the species variety because [6] delimited the species into three varieties based on the size of the fruits and seeds to include; var. africana, var. inversa and var. mollusi with var. africana identified as the biggest.

Treculia africana is found in Senegal, Southern Sudan, Angola, Central Mazambique and Sao Tome [6]and throughout the tropics including West and Central African humid forest zones [3] as well as derived savanna regions. The species is one of the multipotential Nigerian indigenous tropical tree food crops that significantly mitigate seasonal food scarcity. In Nigeria, particularly in the South Eastern States, the species seed ranks first among the popularly consumed food [7,8] and is variously named by different ethnic tribes across Nigeria as 'ukwa' (Igbo), 'bere foo foo' (Yoruba), 'ediang' (Efik and Ibibio), 'ize' (Benin), and 'bafufuta' (Hausa), though "ukwa" is most popular. The most highly sought after part of the species is the seeds that are variously consumed as food such as in pottage, food compliment, snack[7]and it is an alternative to rice and yam[9].Among the Igbos of Nigeria, Treculia has been recognized as the food of choice for royalty, which is specially served at celebrity during fulfillment of social obligations like wedding, traditional feasting such as; title taking, initiation of youths into their age grades, meetings of communal leaders etc.[4,10]. Apart from food 
source, the species seeds play vital roles in improving people's socio- economic life. Inter State trade on the species seeds generates substantial revenue to the resource of the poor rural dwellers and the intermediary traders. Within the South Eastern States, hawkers on Treculia snacks can earn revenue that sustains their families [7,11]. [11] reported that $28 \mathrm{~kg}$ of undehausked / fresh seeds of the species sales at about $\# 500$ while per-boiled and dehausked seeds attract as much as $\# 850$ per $28 \mathrm{~kg}$. The same authors reported a revenue yield of over $\# 25,000$ per tree per year for heavily fruited trees. The chemical nutrient content of the seeds contain digestible proteins, carbohydrates, fat and oil, magnesium, calcium, moisture etc in different proportions $[12,13,14,15]$, which can be recommended to the aged, patients of diabetics, allegery and anemia because of the high percentage content of digestible protein in the species seeds [14] (Table 1).The species plant and seeds may be used as herbal medicine in traditional health care delivery [16] its wood and stem latex are indispensible in bone setting[14].[17]reported that the species wood is a good source of thermal energy (firewood) and very suitable for pulp and paper production due to the woods good fibre qualities (Runkel ratio and fiber lumen). The seeds husk, fruit pulp and leaves have been reported to be an important fodder especially in the dry season when fresh fodder is scarce [12].

Table 1. Approximate compositions of the seeds of African breadfruit (Treculia afriicana)

\begin{tabular}{|c|c|c|c|}
\hline $\begin{array}{c}\text { Chemical } \\
\text { property }\end{array}$ & $\begin{array}{c}\text { Composition } \\
\text { (\%) }\end{array}$ & Elements & $\begin{array}{c}\text { Composition } \\
\text { (mg/100g } \\
\text { DM) }\end{array}$ \\
\hline Carbohydrate & $73.26 \pm 0.01$ & Sodium & $7.10 \pm 0.10$ \\
\hline Crude Protein & $12.47 \pm 0.10$ & Potassium & $587 \pm 0.02$ \\
\hline Fat & $4.23 \pm 0.02$ & Calcium & $165 \pm 0.01$ \\
\hline Ash & $2,26 \pm 0.02$ & Magnesium & $186 \pm 0.01$ \\
\hline Fibre & $1.62 \pm 0.02$ & Iron & $1.66 \pm 0.01$ \\
\hline Moisture & $8.01 \pm 0.10$ & Zinc & $8.50 \pm 0.02$ \\
\hline & & Copper & $3.67 \pm 0.01$ \\
\hline
\end{tabular}

Source: Osabor, et al., (2009).

Phenological events of tropical species especially in Nigeria are strongly related to seasonal changes. [18] reported phenological cycle as a natural phenomena accompanied by corresponding cycles of vegetation growth and reproduction associated with season. Most phenological cycles follow a pattern which may be annual (twelve months), or twice in a year [19,4,20]. [21] reported that variation in seasonal changes can induce a high diversity of phenological pattern. Although, some biological characters of $T$. africana namely semi-deciduous, fruits throughout the year with period of heavy fruiting in the wet season alternating with that of lean fruit production in the dry season are available[22,23], the information on the species phenology appeared scanty. Hence, knowledge of phenological sequence is essential for obtaining information on breeding requirement for species establishment. Therefore, the present study was conducted in two seasons in five different locations to assess the effect of seasonal changes on the species. Also, the variations on the species periods of: flowering, fruit formation, maturity and dropping (harvesting periods), pattern of leaf exchange dispersal in the two seasons were also investigated to obtain information and plan for collecting seeds for sexual propagation, so that the seedlings do not over stay in the nursery before planting in the field.

\section{Materials and Methods}

The study was carried out in five Southeastern States of Nigeria in two seasons, wet (May to October) and dry (November to April), with annual rainfall of 1,600-2,500 $\mathrm{mm}$. The mean temperature ranged from $27^{\circ} \mathrm{C} \pm 2$ to $30^{\circ} \mathrm{C} \pm$ 2 in the wet season and $28^{\circ} \mathrm{C} \pm 2$ to $32^{\circ} \mathrm{C} \pm 2$ in the dry season $[24,25,26]$.The locations randomly selected for the study, were Isulabor (IS), Agulu (AG), Ezzamgbo (EZ), Nenwe (NE) and Okigwe (OK) because of availability of the species (Table 2). The study lasted for three years (2012 -2014) and study visits to each of the study location were made at an interval of one month. Experimental design (Figure 1) was a Randomized Completely Block Design (RCBD) adopted following method of vegetation study [27].

Prior to the study, juvenile plants were ignored because they have not attained reproductive age. Ten trees from each study location were used and species stand at the edge of randomly laid blocks with about $80 \%$ of its branches inside the block be counted for that block. Phenophases of interest on the mature trees covered period and degree of: leaf abscission, bud flush, leaf maturity, flowering, fruit formation, and fruit maturity, pattern of leaf dispersal and dropping of ripe fruits.

Meteorological data for rainfall, relative humidity temperature and vapour pressure were collected, summed up and the mean recorded for the five towns was taken Table 3. The data on Meteorological data were related to the species phenological rhythm. Data obtained from fruit production in each location and season (Mean of ten trees) were subjected to the analysis of variance and the means separated by Duncan Multiple Range Test.

Five (5) soil samples were collected from the five study areas using a sharp Dutch Auger soil sampler by adopting the procedure described by [28]. At each visit, soil samples were randomly collected from five points at $0-15 \mathrm{~m}$ surface and $15-30 \mathrm{~m}$ subsurface respectively around five tree stands. In each location, soil samples obtained were bulked 
together and packaged in labelled collection bag to represent soil from the locations. At the end of soil sample collection, soil samples collected from each location at different periods were lumped together in well tagged collection bags. This represented soil sample from a location and were stored in labeled desiccators prior to analysis. The soil samples were analysed for their physicochemical contents. The samples were analyzed in the Soil Analysis Laboratory of the Department of Soil Science, University of Nigeria, Nsukka.

Table 2. The Study locations and their coordinates

\begin{tabular}{|c|c|c|c|c|}
\hline STATE & TOWN & CODE & LGA & COORDINATES \\
\hline Abia & Isulabor & IS & Umunochi & $5^{0} 51^{1} 0^{\prime} \mathrm{N}, 703110 \mathrm{E}$ \\
\hline Anambra & Agulu & AG & Aniocha & $6.11 \mathrm{~N}, 7.0724 \mathrm{E}$ \\
\hline Ebonyi & Ezzamgbo & EZ & Ohaukwu & $6^{0} 54^{1} \mathrm{~N}, 7^{0} 30^{1} \mathrm{E}$ \\
\hline Enugu & Nenwe & NE & Awgu & $6^{0} 7^{1} 0^{\prime} \mathrm{N}^{0} 7^{0} 31^{1} 0^{\prime} \mathrm{E}$ \\
\hline Imo & Okigwe & OK & Okigwe & $5^{0} 49^{1} 56 \mathrm{~N}, 7^{0} 24^{1} 23 \mathrm{E}$ \\
\hline
\end{tabular}

Table 3. The mean record of Meteorological data collected (Rainfall, relative humidity, temperature and vapour pressure) for the study areas.

\begin{tabular}{|c|c|c|c|c|}
\hline \multirow{2}{*}{ Months } & \multirow{2}{*}{$\begin{array}{c}\text { Temperature } \\
\text { (mean 0C) }\end{array}$} & $\begin{array}{c}\text { Relative } \\
\text { humidity } \\
\text { (mean \%) }\end{array}$ & $\begin{array}{c}\text { Rainfall } \\
\text { (mm) }\end{array}$ & $\begin{array}{c}\text { Vapour } \\
\text { pressure } \\
\text { (Hpa) }\end{array}$ \\
\hline JAN & 27.7 & 62 & Trace & 23.4 \\
\hline FEB & 29.4 & 63 & Trace & 28.1 \\
\hline MAR & 29.3 & 60 & 2.2 & 28.6 \\
\hline APRIL & 28.0 & 63.5 & 162.8 & 29.1 \\
\hline MAY & 28.0 & 75 & 187.4 & 29.1 \\
\hline JUNE & 27.1 & 75 & 403.4 & 28.1 \\
\hline JULY & 26.2 & 78.5 & 130.3 & 27.5 \\
\hline AUG & 25.8 & 77 & 153.2 & 27.5 \\
\hline SEP & 26.4 & 80.5 & 439 & 28.3 \\
\hline OCT & 27.4 & 75.5 & 234.9 & 28.9 \\
\hline NOV & 27.7 & 54.5 & 1 & 29.6 \\
\hline DEC & 26.9 & 37 & 0 & 19.8 \\
\hline
\end{tabular}

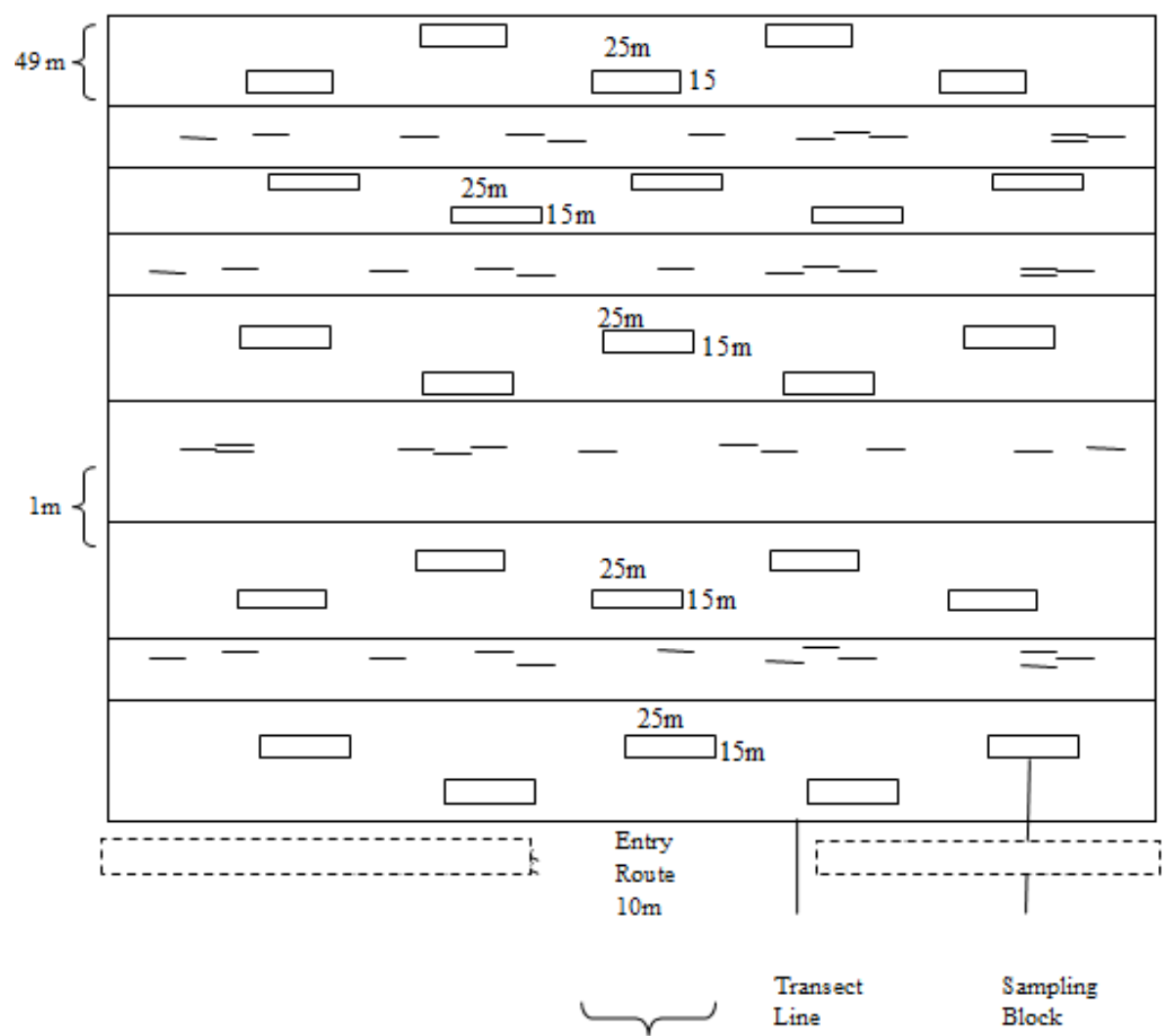

Figure 1. Schematic Diagram Representing the Experimental Layout in the Study areas. 


\section{Results}

In all the locations and seasons, the results of the meteorological factors (Mean monthly: rainfall, relative humidity $(\mathrm{RH})$ temperature and total vapour pressure) showed variations (Table 2). Dry seasons had low monthly record of all meteorological data that were significant. In the dry season, mean monthly rainfall, temperature and relative humidity respectively decreased. Results also showed that mean monthly rainfall (Fig. 2a) was very low but was significant in March and April (2.2 mm and 162.8 $\mathrm{mm})$. However, in the wet season, mean monthly rainfall increased from May to July, with a drop in August before another sharp increase in September. Results observed that mean monthly total vapour pressure and temperature showed the same pattern in variation that were significant from November to March.

The schematic diagram showing the phenophases/ phenological rhythm of Treculia africana in the five different locations is presented in Fig. 1. Generally, in all the locations and seasons, the results of observations on the trees showed that the species is semi-deciduous and bears fruits throughout the year, with the period of heavy fruiting alternating with that of lean fruiting. Heavy fruit production on the trees was observed in the wet season, while lean fruiting was encountered in the dry season.

In all the locations, the result of observations on fruit bearing trees showed that not all the trees reproduced in the same year. It was observed also that some trees standing close to one another did not all reproduce. It was observed that the end of leaf maturity is followed by flower initiation in all the season.

The results also revealed that the species reproductive phases (flowering - fruit maturity and dropping) were associated with simultaneous leaf exchange (leaf abscission, bud flush and leaf maturity). The observed various degrees of leaf exchange took place within the periods of flower and fruit formation to that of fruit dropping in all the locations and seasons respectively. The results observed that in all the locations and seasons, few flowers were initially produced on few branches but later, flowers spread sporadically on the main tree trunks and on big lateral branches which showed no discernable pattern.

In the wet season, heavy flower and fruit periods occurred within mid-May and September. The initial heavy flower formation period started on May and continued till late June. The results further showed that the first set of flowers produced in May developed into fruits that were quite distinguishable from the inflorescence in June. The results showed that fruit maturity stretched from July to August, when the fruits began to drop, and ended in September. The results observed that heavy leaf abscission together with light bud flush occurred on the trees as the flowers and fruits are being formed. Light leaf abscission and heavy bud flush and leaf maturity also took place as fruit maturity sets in. Results revealed that heavy bud flush and leaf maturity dominated leaf abscission after the dropping of the last set of mature fruits (September to October).

The wet season spilled into dry season in November resulting in light flower and fruit periods. The initial light flower formation period started on November and continued till late December. Also, in the dry season, the first set of flowers produced in November developed into fruits in December and fruit maturity started from January to February, when the fruits began to drop, and ended in March. The results observed the same pattern of leaf exchange as with wet season in the dry season and equally revealed that after the dropping of the last set of mature fruits in late March, heavy bud flush and leaf maturity dominated leaf abscission in April before it spilled into May, the onset of wet season.

Generally, the fruit maturity took three months to be accomplished in all the locations and seasons while dropping of mature ripe fruits took one month from February to March and August to September respectively. The results also showed that the last set of fruit dropping in all the seasons was accompanied by intensive leaf formation/maturity and light leaf abscission (i.e. April and October). Finally, flower and fruit abortion were observed in most heavily flowered and fruited trees in all the locations. However, the quantity of aborted fruits were not more than $5 \%$ of the fruits that persisted until maturity and dropping. In the dry season, few cases of flowers drying up on the trees were encountered in all the locations.

Mean number of mature fruit production per tree per year in the five different locations in the wet and dry seasons was summarized in Table 5. The results showed that in the wet season, fruit production per tree in all the locations ranged from $87 \pm 13.78$ to $124 \pm 13.78$. Trees in Nenwe produced the highest number of fruits. This was followed by Okigwe, while Ezzamgbo produced the least $(87 \pm 13.78)$. The grand total of fruit yield for the five locations was 509 in wet season and 352 in dry season.

In the dry season, fruits production ranged from $66 \pm$ 4.27 to $78+4.27$. The highest number of fruits was recorded at Nenwe. This was followed by Okigwe, while the least number was recorded at Agulu (66 \pm 4.27$)$.

Comparing fruit production/ yield by the trees in the five different locations and in the wet and dry season, the results showed that in the wet season, the number of fruits produced (Grand mean, $509 \pm 15.5$ ) was higher than that of the dry season $(352+15.5)$. The results further showed that fruit production in each of the locations was higher in the wet than in the dry season.

The results of observations on the pattern/manner of the dispersal of the abscised leaves showed that the leaves were scattered around the vicinity of the trees. The leaves sandwiched each other at the base of the trees in a mat-like fashion. These observations were consistent in all the locations and for the two seasons. 
The results of the physical properties soils from study areas (Table 14) indicate that soil texture are classified into: Loamy + Sandy (LS), Loamy (L) and Clay + Loamy (CL). From the result, it implies Nenwe had only loamy (L) texture class while others had a heterogeneous texture class. Again, soil collected from Nenwe had the highest percentage clay content (26\%), silt (39\%) but with the least percentages of fine sand $(20 \%)$ and coarse sand $(15 \%)$ content. These differed significantly from all others $(\mathrm{P}<$ 0.05). Soil from Ezzamgbo location had the highest percentage Fine sand $(62 \%)$ with the least percentage clay content $(6 \%)$ and silt $(9 \%)$ while Agulu soil had highest percentage Coarse sand (60\%).

The results of the chemical properties of soils (Table 14) showed that in the $\mathrm{pH}$ values, except Ezzamgbo soil which was slightly alkaline ( $\mathrm{pH} 7.1)$ all other soils sampled were acidic (range, $\mathrm{pH} 5.1$ - pH.6.7). Results observed that the level of the soil acidity $\mathrm{pH}$ value influence the precipitation
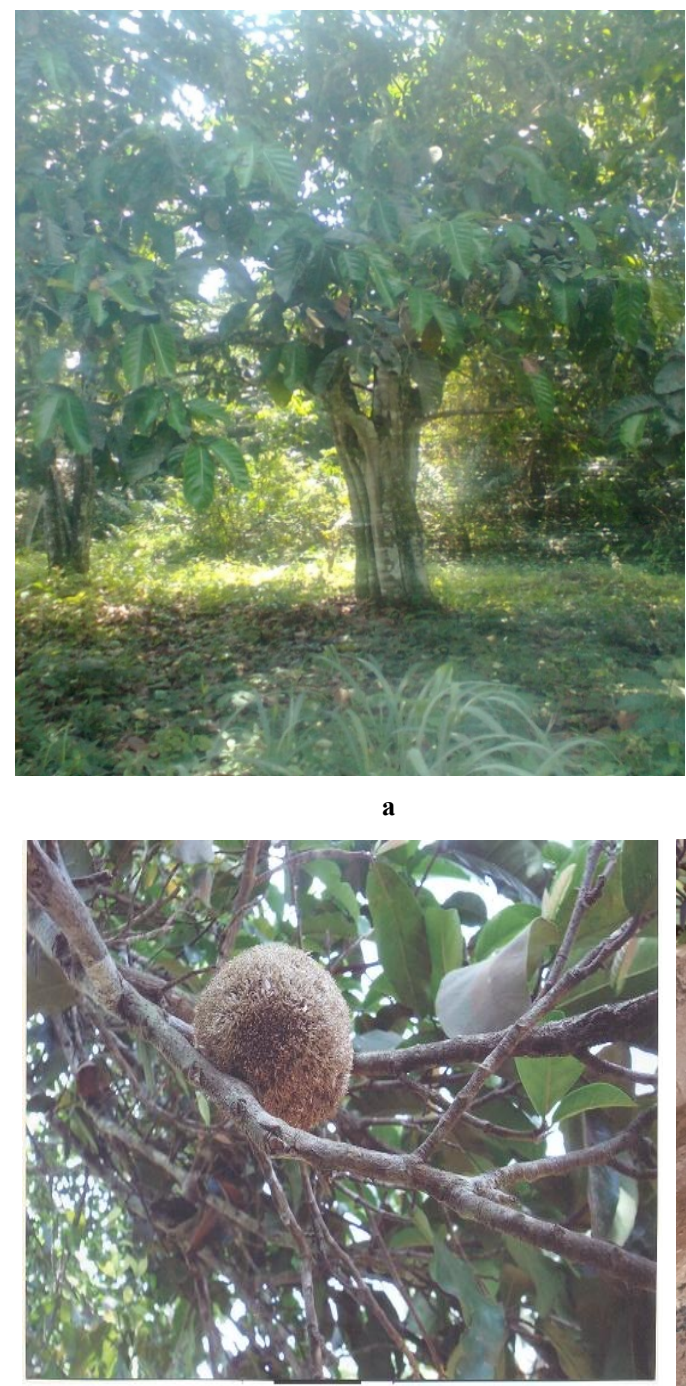

b of nutrient with exchangeable acidity of Aluminum. The results showed that in the soil Carbon and Organic matter contents Okigwe soil had the highest percentage of the carbon content (1.82\%) and Organic matter (3.13) with zero Phosphorus contents, while Ezzamgbo soil had the least percentage Carbon $(0.89 \%)$ and Organic matter $(1.54 \%)$ respectively with highest Phosphorus content (30.78). The results of analysis for exchangeable bases showed that the percentage Nitrogen content range from $0.098 \%$ to $0.210 \%$. Nenwe had the highest Nitrogen $(0.210 \%)$ while Agulu had the least percentage Nitrogen content.

The results showed variations in the chemical contents of soil samples collected from the five different study areas (towns). It was observed that no soil sample from any study area consistently had the highest or the least percentage contents of the exchangeable bases / plant nutrient contents.

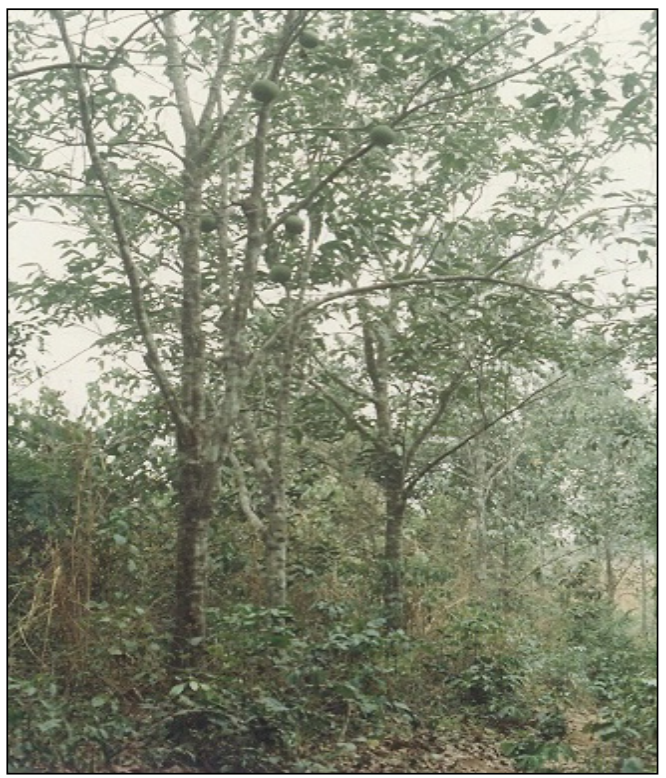

c

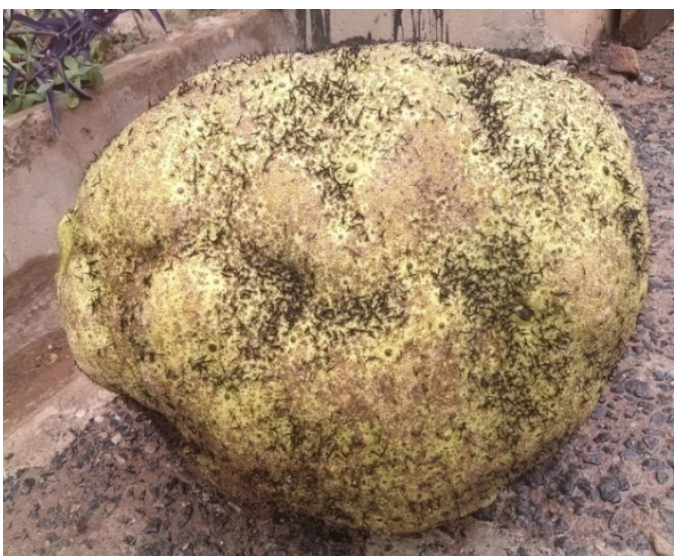

d

Key: a - vegetative plant when leaf exchange is at climax

$\mathrm{b}$ - Flowering plant, $\mathrm{c}-$ Fruiting plant, $\mathrm{d}$ - Mature ripe fallen fruit

Plate 1a-d. The photographs of the Treculia plant showing its phenophases 


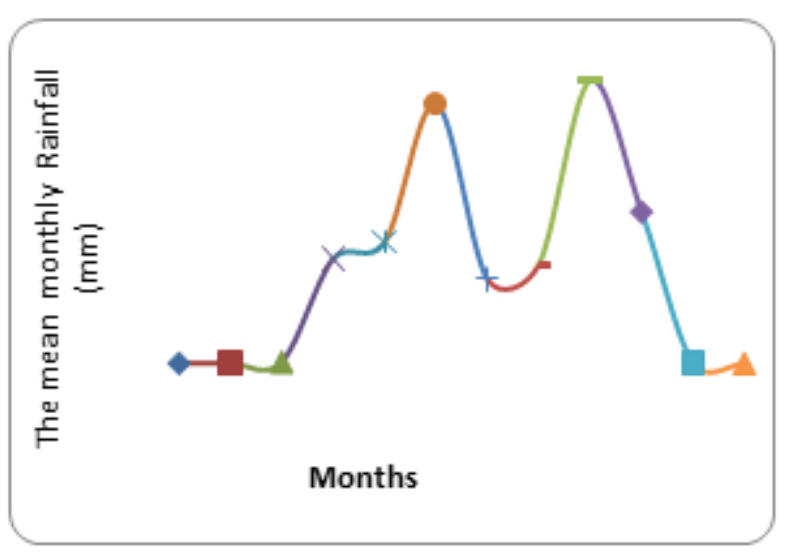

a

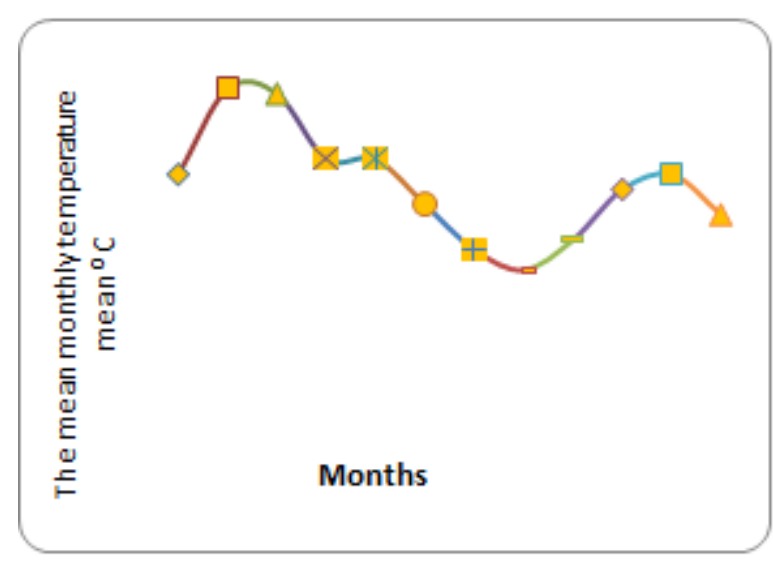

c

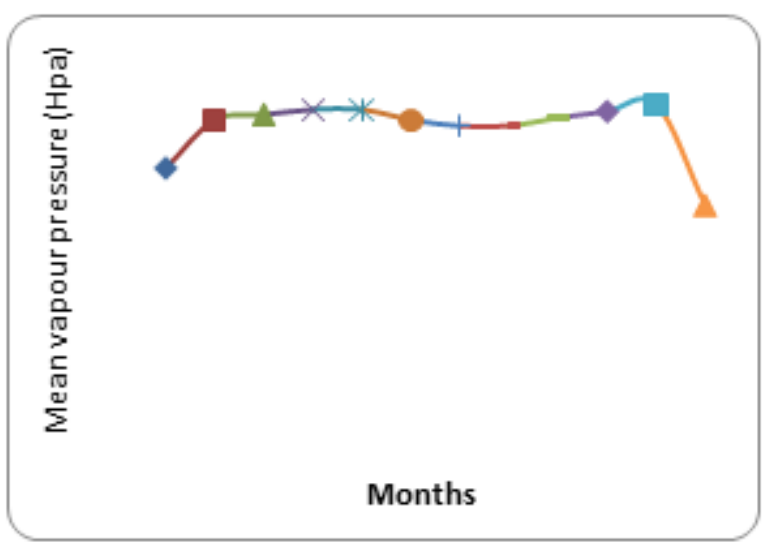

b

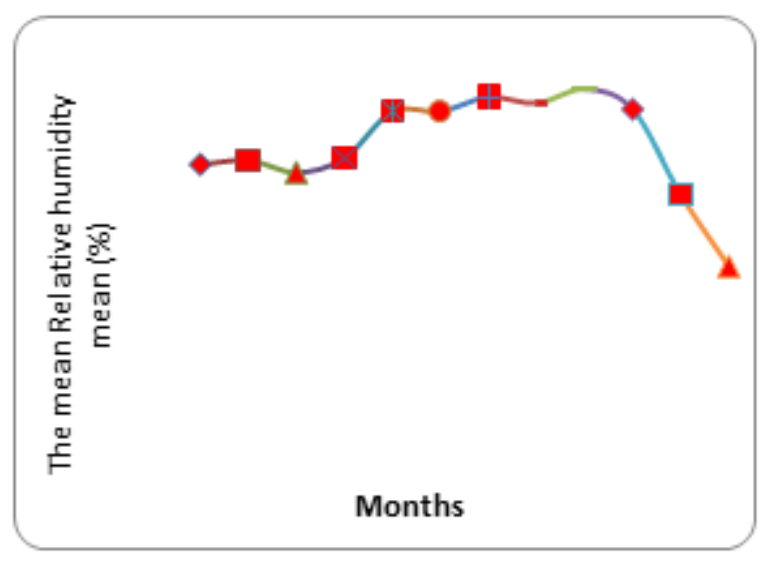

d

Figure 2a-d. The mean monthly record for temperature, relative humidity, rainfall and total vapour pressure for the two seasons.

Table 4a-c. Number of fruit yields per Tree per Location in $2012-2014$ Wet seasons

$$
\text { a-2012 }
$$

\begin{tabular}{|c|c|c|c|c|c|}
\hline Towns & \multirow{2}{*}{ IS } & \multirow{2}{*}{$\mathbf{A G}$} & \multirow{2}{*}{$\mathbf{E Z}$} & \multirow{2}{*}{ NE } & \multirow{2}{*}{ OK } \\
\hline Trees & & & & & \\
\hline T1 & 106 & 102 & 72 & 110 & 104 \\
\hline T2 & 74 & 76 & 105 & 90 & 123 \\
\hline T3 & 102 & 95 & 92 & 130 & 110 \\
\hline T4 & 81 & 80 & 94 & 126 & 90 \\
\hline T5 & 120 & 110 & 80 & 128 & 115 \\
\hline T6 & 84 & 92 & 106 & 132 & 112 \\
\hline T7 & 59 & 89 & 63 & 115 & 119 \\
\hline T8 & 93 & 58 & 108 & 126 & 116 \\
\hline T9 & 89 & 93 & 91 & 119 & 121 \\
\hline T10 & 92 & 85 & 109 & 124 & 110 \\
\hline$\sum \mathbf{X}$ & 900 & 880 & 920 & 1200 & 1120 \\
\hline$-\mathbf{x}$ & 90 & 88 & 92 & 120 & 112 \\
\hline
\end{tabular}

b - 2013

\begin{tabular}{|c|c|c|c|c|c|}
\hline Towns & \multirow{2}{*}{ IS } & \multirow{2}{*}{ AG } & \multirow{2}{*}{$\mathbf{E Z}$} & \multirow{2}{*}{ NE } & \multirow{2}{*}{ OK } \\
\hline Trees & & & & & \\
\hline T1 & 117 & 111 & 76 & 125 & 106 \\
\hline $\mathbf{T} 2$ & 85 & 68 & 85 & 136 & 102 \\
\hline T3 & 113 & 113 & 83 & 129 & 105 \\
\hline T4 & 92 & 96 & 81 & 134 & 115 \\
\hline T5 & 131 & 85 & 74 & 120 & 94 \\
\hline T6 & 95 & 110 & 88 & 100 & 133 \\
\hline T7 & 70 & 99 & 90 & 140 & 97 \\
\hline T8 & 104 & 114 & 96 & 136 & 72 \\
\hline T9 & 100 & 97 & 81 & 138 & 119 \\
\hline T10 & 103 & 77 & 86 & 142 & 87 \\
\hline$\sum \mathbf{X}$ & 1010 & 970 & 840 & 1300 & 1030 \\
\hline $\mathbf{X}$ & 101 & 97 & 84 & 130 & 103 \\
\hline
\end{tabular}


c -2014

\begin{tabular}{|c|c|c|c|c|c|}
\hline Towns & \multirow{2}{*}{ IS } & \multirow{2}{*}{$\mathbf{A G}$} & \multirow{2}{*}{$\mathbf{E Z}$} & \multirow{2}{*}{ NE } & \multirow{2}{*}{ OK } \\
\hline Trees & & & & & \\
\hline T1 & 84 & 77 & 81 & 119 & 121 \\
\hline $\mathbf{T} 2$ & 90 & 86 & 85 & 128 & 110 \\
\hline T3 & 110 & 88 & 82 & 132 & 112 \\
\hline T4 & 113 & 78 & 73 & 126 & 117 \\
\hline T5 & 103 & 73 & 100 & 94 & 120 \\
\hline T6 & 92 & 85 & 81 & 129 & 103 \\
\hline T7 & 98 & 95 & 80 & 123 & 114 \\
\hline T8 & 111 & 99 & 97 & 130 & 119 \\
\hline T9 & 80 & 82 & 87 & 125 & 118 \\
\hline T10 & 89 & 87 & 84 & 114 & 116 \\
\hline$\sum \mathbf{X}$ & 970 & 850 & 850 & 1220 & 1150 \\
\hline $\mathbf{X}$ & 97 & 85 & 85 & 122 & 115 \\
\hline
\end{tabular}

Table 4d-f. Number of fruit yields per Tree per Location in 2012 2014 Dry seasons

d $-\mathbf{2 0 1 2}$

\begin{tabular}{|c|c|c|c|c|c|}
\hline Towns & \multirow{2}{*}{ IS } & \multirow{2}{*}{ AG } & \multirow{2}{*}{$\mathbf{E Z}$} & \multirow{2}{*}{ NE } & \multirow{2}{*}{ OK } \\
\hline Trees & & & & & \\
\hline T1 & 66 & 80 & 64 & 111 & 77 \\
\hline $\mathbf{T} 2$ & 75 & 69 & 62 & 93 & 80 \\
\hline T3 & 73 & 84 & 65 & 110 & 98 \\
\hline T4 & 71 & 67 & 60 & 65 & 73 \\
\hline T5 & 64 & 47 & 54 & 108 & 68 \\
\hline T6 & 78 & 81 & 67 & 82 & 83 \\
\hline T7 & 80 & 38 & 68 & 96 & 64 \\
\hline T8 & 71 & 83 & 65 & 94 & 90 \\
\hline T9 & 86 & 66 & 70 & 107 & 81 \\
\hline T10 & 76 & 55 & 65 & 74 & 46 \\
\hline$\sum \mathbf{X}$ & 740 & 670 & 640 & 940 & 760 \\
\hline $\mathbf{X}$ & 74 & 67 & 64 & 94 & 76 \\
\hline
\end{tabular}

$\mathbf{e}-\mathbf{2 0 1 3}$

\begin{tabular}{|c|c|c|c|c|c|}
\hline Towns & \multirow{2}{*}{ IS } & \multirow{2}{*}{ AG } & \multirow{2}{*}{$\mathbf{E Z}$} & \multirow{2}{*}{ NE } & \multirow{2}{*}{ OK } \\
\hline Trees & & & & & \\
\hline T1 & 66 & 64 & 73 & 65 & 62 \\
\hline $\mathbf{T} 2$ & 72 & 69 & 80 & 66 & 95 \\
\hline T3 & 67 & 64 & 71 & 63 & 82 \\
\hline T4 & 68 & 67 & 77 & 68 & 84 \\
\hline T5 & 65 & 63 & 75 & 63 & 70 \\
\hline T6 & 68 & 61 & 61 & 62 & 96 \\
\hline T7 & 64 & 64 & 68 & 60 & 53 \\
\hline T8 & 64 & 59 & 70 & 63 & 98 \\
\hline T9 & - & 53 & 72 & 58 & 81 \\
\hline T10 & 66 & 66 & 63 & 52 & 99 \\
\hline$\sum \mathbf{X}$ & 600 & 630 & 710 & 620 & 820 \\
\hline $\mathbf{X}$ & 60 & 63 & 71 & 62 & 82 \\
\hline
\end{tabular}

f - 2014

\begin{tabular}{|c|c|c|c|c|c|}
\hline Towns & \multirow{2}{*}{ IS } & \multirow{2}{*}{$\mathbf{A G}$} & \multirow{2}{*}{$\mathbf{E Z}$} & \multirow{2}{*}{ NE } & \multirow{2}{*}{ OK } \\
\hline Trees & & & & & \\
\hline T1 & 39 & 90 & 89 & 70 & 60 \\
\hline $\mathbf{T 2}$ & 73 & 65 & 68 & 85 & 63 \\
\hline T3 & 69 & 69 & 69 & 66 & 48 \\
\hline T4 & 72 & 72 & 70 & 92 & 59 \\
\hline T5 & 61 & 82 & 78 & 83 & 69 \\
\hline T6 & 86 & 73 & 75 & 48 & 89 \\
\hline T7 & 54 & 38 & 57 & 79 & 55 \\
\hline T8 & 82 & 56 & 73 & 82 & - \\
\hline T9 & 100 & 75 & 49 & 100 & 65 \\
\hline T10 & 64 & 60 & 62 & 75 & 72 \\
\hline$\sum \mathbf{X}$ & 700 & 680 & 690 & 780 & 580 \\
\hline $\mathbf{X}$ & 70 & 68 & 69 & 78 & 58 \\
\hline
\end{tabular}

Table 5. Mean Number of Fruit Production in all the Locations per Tree per Year

\begin{tabular}{|c|c|c|}
\hline \multirow[b]{2}{*}{ Locations } & \multicolumn{2}{|c|}{ Mean Number of Fruits } \\
\hline & Wet season & Dry season \\
\hline IS & $96 \mathrm{c}$ & $68 \mathrm{bc}$ \\
\hline $\mathbf{A G}$ & $90 \mathrm{c}$ & $66 \mathrm{c}$ \\
\hline $\mathbf{E Z}$ & $87 \mathrm{c}$ & $68 \mathrm{bc}$ \\
\hline $\mathbf{N E}$ & $124 \mathrm{a}$ & $78 \mathrm{a}$ \\
\hline OK & $110 \mathrm{~b}$ & $72 \mathrm{~b}$ \\
\hline$\sum \mathbf{X}$ & 509.00 & 352.00 \\
\hline $\mathbf{X}$ & 101.40 & 70.40 \\
\hline SE & 13.78 & 4.27 \\
\hline
\end{tabular}


November (dry season starts)

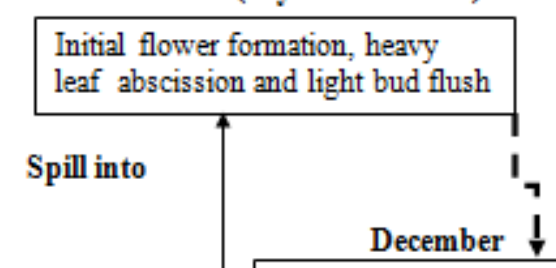

Flowering, Fruit distinction heavy abscission and light bud flush leaf abscission and light bud flush Flowering, fruit formation and leaf exchange

\section{October \\ Leaf exchange (i.e. heavy bud flush and light abscission}

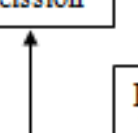

Fruiting, fruit maturity, heavy bud flush and light abscission

\section{February $\frac{1}{7}$}

Fruit maturity, dropping, heavy bud flush and light abscission

\section{March}

Fruit dropping heavy bud flush and light abscision

\section{April}

May (wet season starts)

Initial flower formation, heavy leaf abscission and light bud flush i.e. heavy leaf abscission

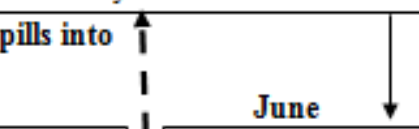

Flowering, Fruit distinction heavy leaf abscission and light bud flush and flowering continued

July

Fruiting, fruit maturity, heavy bud flush and light abscission and flowering continued

\section{August}

Fruit maturity, dropping, heavy bud flush and light abscission

Key:

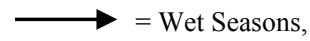

September

Last set of fruit dropping,

heavy bud flush and light abscision

Figure 3. Schematic Diagram Showing T. africana Phenophases in Wet and Dry Seasons.

Table 6. Analytical data physical properties of the soil used in this experiment

\begin{tabular}{|c|c|c|c|c|c|}
\hline $\begin{array}{c}\text { Sample } \\
\text { description. }\end{array}$ & \multicolumn{4}{|c|}{$\begin{array}{c}\text { Texture } \\
\text { Class }\end{array}$} & \multicolumn{4}{|c|}{} \\
\%
\end{tabular}

Key: $\mathrm{L}=$ Loamy, $\mathrm{S}=$ Sandy, $\mathrm{C}=$ Clay

Table 7. The chemical properties analyzed

\begin{tabular}{|c|c|c|c|c|c|c|c|c|c|c|c|c|c|c|}
\hline \multirow[t]{2}{*}{$\begin{array}{c}\text { Sample } \\
\text { VV V } \\
\text { description }\end{array}$} & \multicolumn{2}{|c|}{ pH value } & \multicolumn{2}{|c|}{$\begin{array}{c}\text { Organic } \\
\text { Matter \% }\end{array}$} & \multirow{2}{*}{$\begin{array}{l}\mathbf{N} \\
\%\end{array}$} & \multicolumn{4}{|c|}{ Exch. Base (me/100g) } & \multirow{2}{*}{$\begin{array}{c}\text { CEC } \\
\mathrm{Me} \\
100 \mathrm{~g} \\
\end{array}$} & \multirow{2}{*}{$\begin{array}{c}\text { Base } \\
\text { sat. }\end{array}$} & \multicolumn{2}{|c|}{$\begin{array}{l}\text { Exch Acidity } \\
\text { (me/100g) }\end{array}$} & \multirow{2}{*}{$\begin{array}{c}\mathbf{P} \\
\mathrm{Ppm}\end{array}$} \\
\hline & $\mathrm{H}_{2} \mathrm{O}$ & $\mathrm{KCL}$ & $\mathrm{C}$ & $\mathrm{OM}$ & & $\mathrm{Na}^{+}$ & $\mathrm{K}^{+}$ & $\mathrm{Ca}^{2}$ & $\mathrm{Mg}^{3}$ & & & $\mathrm{Al}^{3+}$ & $\mathrm{H}^{+}$ & \\
\hline IS & 6.7 & 5.9 & 0.96 & 1.66 & 0.098 & 0.10 & 0.11 & 8.00 & 4.00 & 13.20 & 92.50 & - & 1.20 & 25.18 \\
\hline $\mathrm{AG}$ & 6.7 & 5.7 & 0.96 & 1.66 & 0.070 & 0.06 & 0.12 & 5.20 & 1.20 & 10.00 & 65.80 & - & 1.40 & 12.12 \\
\hline EZ & 7.1 & 6.2 & 0.89 & 1.54 & 0.098 & 0.06 & 0.06 & 8.40 & 4.00 & 14.60 & 85.75 & - & - & 30.78 \\
\hline NE & 5.6 & 4.5 & 1.34 & 2.30 & 0.210 & 0.06 & 0.15 & 7.20 & 1.20 & 30.40 & 28.32 & 1.20 & 1.20 & 26.11 \\
\hline OK & 5.1 & 4.2 & 1.82 & 3.13 & 0.112 & 0.08 & 0.04 & 6.40 & 1.20 & 18.40 & 41.96 & 0.80 & 0.80 & _ \\
\hline
\end{tabular}




\section{Discussion}

Reports on the phenology of different plant species abound[29,18,30], but detailed reports on the phenophases of African breadfruit, Treculia africana Decne, Moraceae, a multipotential Nigerian indigenous food tree crop, appear scarce. Available information on the species phenophases showed that Treculia africana is semi deciduous, yields fruits throughout the year, with the period of heavy fruiting alternating with that of lean fruit yield $[7,8,31,32,33]$. Information on the impact of climatic factors and effect of soil variation on the species phenological rhythm appears scarce.

The results reported increase in mean monthly rainfall with a drop in August. The findings of this study suggest that the very drop in mean monthly rainfall in August was probably due to August break. This agreed with earlier reports,[32,34] [18,30]. [18] described the decreases as well as increases of rainfall, relative humidity and temperature in the dry and wet seasons as distinct feature of dry and wet seasons, which in turn affects plant phenophases. Therefore, flowering and fruiting intensities responds differently to changes in monthly rainfall.

The results of observations on the phenophases of $T$. africana showed varying degrees of overlapping between the reproductive (flowering to fruit maturity) and the vegetative (leaf exchange) phases. The observations were common feature in all the five different studied locations. In this study, the sporadic spread of the flowers on the main trunk and big lateral branches which may be accompanied with the simultaneous leaf exchange (leaf abscission and bud flush) always made the flowers of this species to be inconspicuous. This finding suggests that studies on the yield of this can only be made possible when the flowers produced might have developed into fruits and became clearly distinct.

There are no earlier reports on the rhythm of the species reproductive and vegetative phenophases. Few available reports only pointed out that the species is semi-deciduous. Information on the periods of flowering, fruit formation and development were not reported $[35,17,8,36,33]$. In this study, the observed light leaf abscission, heavy bud flush and leaf maturity suggest mobilization of nutrients for the development of the fruits. Mature leaves photosynthesize to beef up nutrients from the soil, while dropped leaves help reduce evaporation of water and add to the available nutrients in the trees. The knowledge of the periods of flowering can be capitalize upon by budders / grafters to obtain bud woods for budding or twigs for grafting. [12,37] reported that bud woods/twigs obtained when the parent stock is in flower enhances reductions in the gestation periods and growth in height of the budded /grafted seedlings.

Periods or months when mature ripe fruits drop from the tree as they (fruit) are traditionally not harvested have not been clearly reported. Several reports pointed out that the fruits are more available in the wet season than in the dry season $[37,7,14]$. In this study, dropping of mature ripe fruits from the trees in dry season, light fruiting period stretched from January to March with a peak in March. During the heavy fruiting periods in the wet season, mature ripe fruit start dropping from July to late September with a peak in August. Except in wet season, this finding on periods of fruit dropping coincided with famine periods, when most of the conventional staple food sources are off-season. Hence, availability of the species seeds variously used as food mitigates food scarcity. It also helps tree owners plan for fruit gathering and processing for the seeds. The sale of the seeds also generates revenue for the tree owners and intermediary traders. The results also showed that at the termination of fruit dropping in September, leaf exchange (heavy bud flush and light leaf abscission continued until October when the phenophase spilled into dry season in November.

Reports linking the species wet and dry season phenophases appear lacking. Most authors simply reported that the plant species produced more fruits in the wet than in the dry season $[18,37,7,11]$. In this study, the termination of wet season phenological rhythm spilled into and started that of the dry season in December.

The results showed that in December (Inception of dry season), sporadic flowering was observed on some branches of the trees, irrespective of location. This was accompanied by leaf maturity, bud flush and light leaf abscission. Fruit formation was also observed on some trees in the late December. The results further showed that fruit maturity and dropping stretched from January to mid April. The results further showed that irrespective of location, flowering, fruit maturity and dropping were accompanied by different degrees of leaf exchange. The results further showed that the dry season phenological rhythm terminated in April (Dry season) and spilled into May, the wet season.

Apart from using the seeds variously as food, revenue generation, there are no information on the other uses of the seed and leaves that dropped throughout the year. The seeds produced in the dry season play dual roles. Firstly, the seeds are used to raise seedlings that can be planted out in the field early in the wet season, thus ensuring for the survival and establishment of the seedlings. [38] reported that survival of large quantity of seedlings in the field is important in the conservation of the species for future biotechnological exploitation of their resources. Secondly, nurserymen plan for seed collection for raising seedlings. The seed husks and fruit pulp considered as agricultural waste can be utilized as fodder.

Many authors reported that the species has periods of heavy fruit production (Wet season) and lean fruit yield, in dry season $[31,32,33,39]$. The authors did not quantify the fruit yields in both wet and dry seasons. In this study, 101.4 \pm 15.5 fruits per tree were recorded in the wet as against $70.4 \pm 15.5$ per tree in the dry season. The results agreed 
with earlier reports in that more fruits were produced in the wet than in the dry season. The high fruit production in the wet season could be related to favourable climatic and environmental factors that were lacking in the dry season. Wet season is characterized by mineralization of decayed litters (leaves) that supplied chemical nutrients to the trees, abundant rainwater that supplied moisture regularly to the trees, as well as moderate temperature. The synergistic effect of these factors largely favoured the trees metabolic activities more in the wet than in the dry season.

The findings of this study on the abscised leaves showed that they (leaves) were "arranged" in a mat - like form around the vicinity of the trees, thus covering the trees base. The results of this observation in all the locations agreed with that of earlier report [6]. The pattern of the Treculia leaf dispersal suggested that the leaves possibly mulched the soil, reducing water loss by evaporation in the dry season, while in the wet season leaves that abscised in the previous seasons decayed and mineralizes, thus returned nutrients to the soil for the plant use.

The result of shows that locations analyzed soils were heterogeneous i.e. varied in percentages all the physical and chemical contents contained. Results showed significant difference $(\mathrm{P}>0.05)$ for the percentage content of clay, silt, fine and coarse sand in physical properties and for the amounts of organic matter, soil $\mathrm{pH}$, soil base saturation, Nitrogen, CEC, exchangeable acidity and bases in chemical contents of the soils from the study locations. This agreed with earlier reports in [40] that the soils from different locations in South Eastern Nigeria varied in chemical properties as well as in clay minerals during their studies on characterization: chemical and mineralogical properties of soil in South Eastern Nigeria. Also, these tremendous variation found in soil properties confirmed the earlier reports that such can affect vegetation growth, plant form and development. In this findings, it implies that T. africana grows well even in high acidic or alkaline soil content.

Based on the findings of this study, it can be concluded that: the species phenophases (Reproductive and vegetative) overlapped one another. Periods of fruit dropping in the wet season stretched from July to September and in the dry season, from late February to April. The absence of differences in the species phenology in all the locations, implied that it (Phenological rhythm) is inherent in the species.

\section{REFERENCES}

[1] Mabo, O.O., Lakami, O.O. and Olusegun, O.T. Germination Ecology of Treculia africana. Nigerian Journal of Botany, 1: 66 - 72, 1988.

[2] Okusanya, O.T., Lakanmi, O.O. and Osuagwu, A.E. Some factors affecting the seedling growth and survival of Treculia africana. Journal of Tropical Forest Science, 4: 64
$-79,1991$.

[3] Mbakwe, Roy. The influence of budwood physiology on the gestation period of fruit crops: Studies on Treculia africana (African breadfruit). Journal of Agriculture and Food Science, 3 (1):1- 4, 2005.

[4] Amujiri, A. N. Studies on the morphology, phenology and effect of location on the germination of African Breadfruit (Treculia africana) Decne. Unpublished Thesis submitted in partial fulfillment for the award of Ph.D in Ecology, Department of Plant Science and Biotechnology, University of Nigeria, Nsukka 180pp, 2016.

[5] Nzekwe, U., Onyemelukwe, A. B. and Eze, O. I. Studies on some aspects of agronomic problems of some indigenous food crop resources. International Congress on Industrial Utilization of tropical plants and the conservation of biodiversity (DOCP) Nike-Enugu Nigeria, 15pp ,1993.

[6] Okafor, J.C. Trees for food and fodder in the Sahara area of Nigeria. International Tree Crops Journal, 1:131-141, 1981.

[7] Baiyeri, K.P. and Mbah, B.N. (2006). Effects of soilless and soil-based nursery media on seedling emergency growth and response to water stress of African Breadfruit (Treculia africana Decne). African Journal of Biotechnology 5(15):1405-1410, 2006.

[8] Nzekwe U, and Amujiri, A.N. Effect of media on the germination of the seeds of African Breadfruit, Treculia africana, Decne. var. africana Moraeace. International Journal of Scientific Research. 1(1): 119 - 126, 2011,

[9] NAC (Nutrecul Agroforestry Company). Treculia africana. Assessed on 25 May, 2015 from http://www.nutrecul.agroforestry.com/index-9.htm, 2013.

[10] Nwosu, M.O. An Ethnobotanical Study of Plants in Igboland (Nigeria). Baesseler Archiv. Von Dietrich Reimer Verlag. Benlin Bd 38: 119-132, 1990.

[11] Nzekwe, U., Ojeifor, I.M. and Nworie, H.E. Assessment of gestation period and economic yield of African breadfruit Treculia africana Decne, Moraceae. Journal of Tropical Agriculture, Food, Environment and Extension. (3): 18-23, 2010.

[12] Okafor, J.C. Horticulturally promising indigenous wild plant species of Nigeria forest zone. Acta Horticultura, 123:185-196, 1983.

[13] Arigbede, O.M., Anele, U.Y., Jolaosho, A.O., Onifade, O.S. and Wahab, T.A. Chemical composition and in vitro gas production of African breadfruit (Treculia africana) Decne. Archivos de Zootechia, 57 (218): 113 - 121, 2008.

[14] Nuga O.O., and Ofodile E.A.U. Potentials of Treculia africana Decne - An Endangered Species of Southern Nigeria. Journal of Agriculture and Social Research (JASR) 10 (2): 21-25, 2010.

[15] Osabor, V.N., Ogar, D. A., Okafor, P.C. and Egbung, G. E. Profile of the African breadfruit (Treculia africana). Pakistan Journal of Nutrition 8(7): 1005- 1008, 2009.

[16] Hassain, Eshrat H.M.A. Hypoglycaemic,hypolipidemic and antioxidant properties of combination of Curcumin from Curcumalonga, Linn, and partially purified product from Abromaaugusta Linn, in Streptozotocin induced diabetes. 
Indian Journal of Clinical Biochemistry. 17(2): $33-43$, 2002.

[17] Amujiri, A. N. The effects of media and shelf-life on the germination of seeds of African breadfruit,Treculia africana var. africana Decne. Unpublished Dissertation submitted in partial fulfillment for the award of M.Sc in Ecology, Department of Plant Science and Biotechnology, University of Nigeria, Nsukka 52pp. 2009.

[18] Chapman, C.A., Chapman, L. J., Struhsaker,T.T., Zanne, A. E., Clark, C.J. and Poulsen, J. R. A long term evaluation of fruiting phenology: Importance of climate change. Journal of Tropical Ecology 21: 31- 45, 2005.

[19] Murali, K. S. and Sukumar, R. Reproductive phenology of tropical dry forest in Mudumalai, Southern India. Journal of Ecology. 82: 759 - 780, 1994.

[20] Osayi, E.E. Studies on the morphology, phenology and effect of seed germination of Pentacletra microphylum. Unpublished Thesis submitted in partial fulfillment for the award of Ph.D in Ecology, Department of Plant Science and Biotechnology, University of Nigeria, Nsukka, 2016.

[21] Menzel,A.,Estrella, N. and Tesica,A. Temperature response rates from long term phenological records. Climate Research 30:21 - 28, 2005.

[22] Okafor, J.C. Improving edible species of forest products In: FAO Corporate document repository (Forest Products). Unasylva, No. 165.

http://www.fao.org/docrep/u2440e/u2440e04-..htm.Retriev ed on 25th May 2015, 2001

[23] Taiwo, O.O. (2007). "Breadfruit as a key component of sustainable livelihoods in Nigeria, Prospects, opportunities and challenges." Acta Hort. 757. Retrieved on May, 2012 from http://www.jeffmarck.net/BreadfruitRevolution.htm, 2007.

[24] Obi, M.E. Run-off and soil loss from oxisol in Southeastern Nigeria under various management practices. Agricultural Water Management. 5(1): 193-203, 1982.

[25] Udo, B. U., Utip, K. E., Inyang, M. T. and Idungafa, M. A. Fertility assessment of some Inland depression and floodplain (wetland) soils in Akwa Ibom State. Agro-Science Journal of Tropical Agriculture, Food, Environment and Extension. 8(1): 14 - 19, 2009.

[26] Jidere, C.M. and Akamigbo, F.O.R. Hydrocarbon degradation in poultry droppings cassava peels-amended Typic Paleustults in Southeastern Nigeria. Agro- Science Journal of Tropical Agriculture, Food, Environment and Extention. 8(1): 24-30, 2009.

[27] Frank, H. and Athone, S. Statistics Concepts and Applications. Cambridge University Press, Great Britain. $317 \mathrm{pp}, 1995$.
[28] Usman, S.S. Ecological Studies of Opi Lake Savanna Woodland. Unpublished Ph.D. Thesis, Dept. of Botany, University of Nigeria, Nsukka, 158pp, 1990.

[29] Whitmore, T.C. An Introduction to Tropical Rainforests. Oxford University Press, Oxford, UK. 330 pp, 1998.

[30] Couralet, C. Community dynamics, phenology and growth of tropical trees in the Rain forest reserve of Luki, Democratic Republic of Congo. Unpublished Ph.D thesis. Faculty of Bioscience Engineering, Ghent University, Belgium. 173pp, 2010.

[31] Okusanya, O.T, Lakanmi, O.O. and Osuagwu, A.E. (1990). Some factors affecting the seedling growth and survival of Treculia africana. Journal of Tropical Forest Science, 4: 64 -79 .

[32] Berlin, K. E., Pratt, T. K., Simon, J. E., Kowalsky, J. R. and Hatfield, J. S. Plant phenology in a cloud Forest on the Island of Maui, Hawaii. Biotropica 32: 90 - 99, 2000.

[33] Jeff, M. Tropical Africa's Breadfruit Revolution. jeff@jeffmarck.net. Breadfruit Revolution West Africa Retrieved on May, 2012 from http://www.jeffmarck.net/BreadfruitRevolution.htm, 2012.

[34] Akachukwu, A.E. The Influence of Environmental Factors on Wood Growth of Trees in the Savanna. Proceedings. MAB. State of Knowledge Workshop on Nigeria. Savanna Kainji, Nigeria pp 58- 66, 1980.

[35] Chapman, C.A., Wrangham, R.W., Chapman, L.J., Kennard, D.K. and Zanne, A.E. Fruit and flower phenology at two sites in Kibale National Park, Uganda. Journal of Tropical Ecology 15:189-211, 1999.

[36] Jones, Ragone, Aiona, Lane and Murch,P. Breadfruit nutrients in West Africa, population pyramids and Breadfruit pyramids. Breadfruit Revolution West Africa. http://www.jeffmarck.net/breadfruitrevolution.htm, 2011.

[37] Mbakwe, Roy. The influence of budwood physiology on the gestation period of fruit crops: Studies on Treculiaafricana (African breadfruit). Journal of Agriculture and Food Science, 3 (1):1- 4, 2005.

[38] Nzekwe U, and Amujiri, A.N. The effect of storage duration and methods on the shelf - life of the seeds of African breadfruit, Treculia africana, Decne. Moraeace. International Journal of Scientific Research. 3(1): 15 -21, 2013.

[39] Efemena, D. D. Propagation of Treculiaafricana as influenced by seed storage and propagation media. Agricultura Tropica et Subtropica 46 (2): 52-57, 2013.

[40] Asadu,C.L.A., Akamigbo,F.O.R., Ezuma, H.C and Nweke, F.I.The characterization ofSselected yam growing soils in South-eastern Nigeria: Chemical and mineralogical properties Nigeria Agricultural Journal 24:71-86, 1990. 